\title{
Contrasting patterns of growth and migration of tropical anguillid leptocephali in the western Pacific and Indonesian Seas
}

\author{
Mari Kuroki ${ }^{1, *}$, Jun Aoyama1, Michael J. Miller ${ }^{1}$, Sam Wouthuyzen $^{2}$, Takaomi Arai ${ }^{3}$, \\ Katsumi Tsukamoto ${ }^{1}$ \\ ${ }^{1}$ Ocean Research Institute, The University of Tokyo, 1-15-1 Minamidai, Nakano, Tokyo 164-8639, Japan \\ ${ }^{2}$ Research Center for Oceanography, Indonesian Institute of Sciences, Ancol Timur, Jakarta 11480, Indonesia \\ ${ }^{3}$ International Coastal Research Center, Ocean Research Institute, The University of Tokyo, 2-106-1 Akahama, Otsuchi, \\ Iwate 028-1102, Japan
}

\begin{abstract}
In order to improve understanding of the larval migration and early life history characteristics of 4 tropical eels, Anguilla marmorata, A. bicolor pacifica, A. celebesensis and A. borneensis, the leptocephali, metamorphosing leptocephali and oceanic glass eels collected during 8 cruises in the western Pacific and Indonesian Seas from 1991 to 2002 were analyzed. The leptocephali of A. celebesensis and A. borneensis were collected only in close proximity to their relatively small species ranges in the Indonesian Archipelago and were found to have faster growth than the other 2 species with small-scale local migrations. The more widely distributed species A. marmorata and A. bicolor pacifica were collected in most sampling areas. Small leptocephali of A. marmorata were collected only to the west of the Mariana Islands, and only larger specimens, metamorphosing leptocephali, or oceanic glass eels of both species were collected in the Indonesian Seas. These distributions suggested that the 2 species have intermediate-scale migrations compared to other anguillid eels. The leptocephali of all 4 species appeared to reach a fully grown size of around $50 \mathrm{~mm}$, which is considerably smaller than the maximum size of temperate anguillid leptocephali, and their growth was predominantly faster than that of temperate species. These data and recently derived molecular phylogenetic relationships among all anguillid species in the world suggest that the long spawning migrations of temperate eels evolved from much shorter migrations of tropical species, whose larval growth was faster and whose maximum larval sizes were smaller.
\end{abstract}

KEY WORDS: Leptocephalus $\cdot$ Eel $\cdot$ Otolith $\cdot$ Growth $\cdot$ Metamorphosis $\cdot$ Migration

\section{INTRODUCTION}

After the famous discovery of the spawning areas of the Atlantic eels Anguilla anguilla and A. rostrata in the Sargasso Sea by the Danish oceanographer Johannes Schmidt (Schmidt 1925), there has been considerable interest in the long spawning migrations of anguillid eels. Equally remarkable are their long larval migrations of thousands of kilometers from the Sargasso Sea to North America, Europe and North Africa (McCleave 1993). Anguillid eels are able to make such long- distance larval migrations because of their extraordinarily long larval stage, called a 'leptocephalus', which is unique to the Anguilliformes and the other orders of the Elopomorpha (Inoue et al. 2004). These laterally compressed and transparent larvae reach larger sizes and have longer larval durations than most other fish larvae, and can drift long distances from their ocean spawning areas to their freshwater growth habitats.

Another temperate anguillid, the Japanese eel Anguilla japonica, also has a long spawning migration, and its leptocephali drift in the North Equatorial Cur- 
rent (NEC) from west of the Mariana Islands in the western North Pacific (WNP) to its recruitment areas in East Asia (Tsukamoto 1992). A similar spawning area in the South Equatorial Current (SEC) also appears to be used by A. australis from Australia and New Zealand (Jellyman 1987, Aoyama et al. 1999). Therefore, most temperate anguillids appear to have very similar large-scale migrations and spawn in areas that enable their leptocephali to use low-latitude westward-flowing currents such as the NEC and SEC to transport them thousands of kilometers back to their juvenile growth habitats (Tsukamoto et al. 2002).

Recently, however, it has been shown that some tropical anguillid eels have much shorter local migrations and spawn over the deep waters adjacent to their freshwater growth habitats in the Indonesian Seas (Aoyama et al. 2003). The presence of small leptocephali of Anguilla celebesensis and A. borneensis near Sulawesi Island of central Indonesia indicated that these tropical eels do not migrate very far to spawn, because they have relatively small species ranges, with $A$. celebesensis being found from Sulawesi Island north through the Philippines and east to western New Guinea, and A. borneensis being endemic to the eastern coast of Borneo (Kalimantan) (Ege 1939). In contrast, 2 other tropical eels, A. marmorata and $A$. bicolor pacifica, which are also found in the area around Sulawesi Island, have much wider species ranges and apparently different life histories. A. marmorata appears to have as many as 6 different populations across its range from the Indian Ocean through Indonesia up to southern Japan and across the tropical western South Pacific (Ishikawa et al. 2004). One spawning area of this species appears to be in the NEC region of the WNP in an overlapping area with A. japonica (Tsukamoto 1992, Aoyama et al. 1999, Miller et al. 2002), but the spawning area of $A$. bicolor pacifica is unknown.

These findings suggest that the life histories of tropical anguillid eels may be much more diversified than those of temperate species. Two-thirds of the 18 species/subspecies of anguillid eels worldwide are tropical species (Ege 1939, Castle \& Williamson 1974), so learning about the life histories of tropical species, which appear to be the most ancestral (Aoyama et al. 2001), is essential for understanding the evolution and larval ecology of this remarkable group of catadromous fishes. However, until recently, almost all studies on the early life history of anguillid eels have been on temperate species (see Schmidt 1925, McCleave 1993, Tsukamoto et al. 2003), and relatively little information has been published on the larval distributions and growth rates of tropical anguillid eels (Jespersen 1942, Aoyama et al. 1999, Arai et al. 2001a). Some studies have examined the growth rates of temperate species of leptocephali based on otolith analysis (Castonguay 1987, Tsukamoto 1989, Tsukamoto et al. 1992, Arai et al. 1997, Ishikawa et al. 2001), but the larval growth rates of most species of tropical anguillids have never been studied.

The Carlsberg Foundation's Around the World Expedition studied the distribution of tropical anguillid leptocephali from 1928 to 1930 in the Indo-West Pacific and Indian Oceans (Jespersen 1942), but the clarity of their findings was reduced by an inability to identify some tropical anguillid species because of a major overlap in the critical morphological characters used for identification. Because of this, information about the spawning areas and larval life histories of most tropical eels has been lacking. This problem of identifying tropical anguillid leptocephali has been overcome by the development of genetic identification techniques (Aoyama et al. 1999), and there have been a variety of surveys for anguillid leptocephali in the western Pacific and Indonesian Seas in the last decade.

In the present paper we report on the larval distributions of 4 tropical anguillid eels, Anguilla marmorata, A. bicolor pacifica, A. celebesensis and A. borneensis, using data from 8 sampling surveys since 1991, and we analyze the otolith microstructure of 123 tropical eel leptocephali of these species collected primarily during some of the more recent cruises. This analysis includes data on $A$. celebesensis and A. borneensis, whose leptocephalus otoliths have never been described. The specific objectives of this study were to: (1) compare the species distributions and size ranges; (2) analyze the otolith microstructure to determine early life history parameters such as the age, growth and hatching dates of the leptocephali of these tropical eels; and (3) evaluate these findings in relation to information about temperate species of anguillid leptocephali, to gain a greater understanding of the types of larval migration and the evolution of migration in anguillid eels.

\section{MATERIALS AND METHODS}

Collection and species identification. Leptocephali, metamorphosing leptocephali and oceanic glass eels of Anguilla marmorata, A. bicolor pacifica, A. celebesensis and $A$. borneensis were collected during 6 cruises of the RV 'Hakuho Maru' of the Ocean Research Institute, University of Tokyo, and 2 cruises of the RV 'Baruna Jaya VII' of the Indonesian Institute of Science in the Indo-Pacific region from 1991 to 2002 (Table 1, Fig. 1). We have included some distribution and otolith microstructure data from previous reports from 4 of these cruises (see Aoyama et al. 1999, 2003, Arai et al. 2001a, Miller et al. 2002) and have combined these data with more recent collection and otolith data 


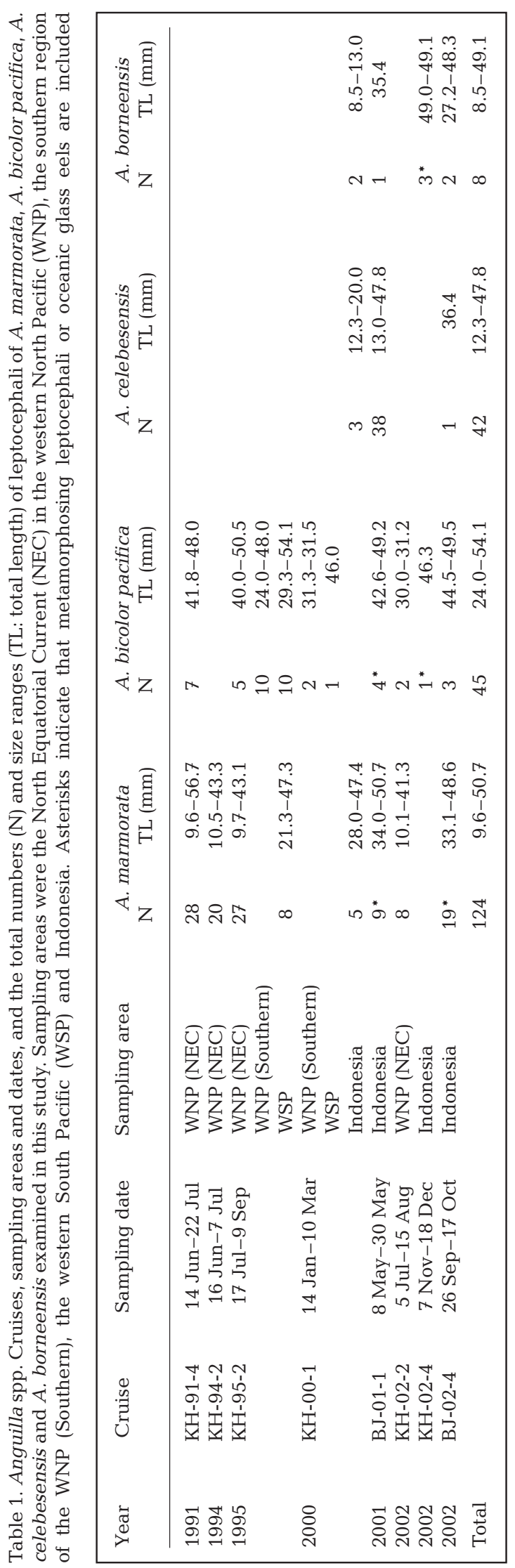

of additional leptocephali. All larvae were collected with $3 \mathrm{~m}$ Isaacs-Kidd Midwater Trawls (IKMT), with $8.7 \mathrm{~m}^{2}$ mouth openings and either 0.5 or $1.0 \mathrm{~mm}$ mesh, which were fished down to depths of 100 to $600 \mathrm{~m}$. Specimens were sorted from the plankton samples, their total length (TL) was measured, and the meristic characters were examined before preservation in $95 \%$ ethanol. Some specimens of A. marmorata in the NEC region reported by Miller et al. (2002) were only identified based on morphological characters, as were the specimens of $A$. bicolor pacifica in the same region during the 1991, 1994 and 1995 cruises. During the 1995 cruise most leptocephali were genetically identified (Aoyama et al. 1999), as were all specimens during subsequent cruises.

Genetic identifications were made in the laboratory by comparing their mitochondrial DNA $16 \mathrm{~S}$ ribosome RNA (mtDNA 16S rRNA) sequences with those of morphologically well-identified adults. Total genomic DNA was extracted according to a standard protocol (Aoyama et al. 1999). A portion of the mtDNA 16S rRNA gene (about 500 base pairs) was amplified by polymerase chain reaction (PCR) using 2 oligonucleotide primers, L2510 and H3058. Amplification parameters were 30 cycles of denaturation at $94^{\circ} \mathrm{C}$ for $30 \mathrm{~s}$, annealing at $58^{\circ} \mathrm{C}$ for $30 \mathrm{~s}$ and extension at $72^{\circ} \mathrm{C}$ for $60 \mathrm{~s}$. The PCR products were sequenced and directly compared to the deposited data in DDBJ (DNA databank of Japan, Accession Numbers: AB021748 to AB021764).

Otolith analysis. The sagittal otoliths, the largest of 3 pairs of otoliths in the inner ear, were extracted from 95 specimens, embedded in epoxy resin (Epofix, Struers) and mounted on glass slides. The otoliths were ground to near the core using a grinding machine equipped with a diamond cup-wheel with 70 and $13 \mu \mathrm{m}$ diamond paste (Discoplan-TS, Struers), and further polished to expose the core on an automated polishing wheel with 6 and $1 \mu \mathrm{m}$ diamond paste (Planopol-V, Struers). After cleaning the surface of each otolith, they were etched with $0.05 \mathrm{M} \mathrm{HCl}$ and vacuum coated with Pt-Pd in an ion-sputterer for scanning electron microscope observations (SEM, Hitachi $\mathrm{S}-4500$ ). The number of successive rings from the hatch check (Arai et al. 1997) to the edge was considered to be the age of each specimen. Hatching dates were determined by back-calculating from the date of capture using the total number of increments in the otoliths. The data from the otolith microstructure of the 28 specimens of Anguilla marmorata and A. bicolor pacifica that were analyzed by Arai et al. (2001a) using the same methods were also included in the present comparisons of growth and hatching dates, making a total of 123 specimens that were used in the present analyses. 


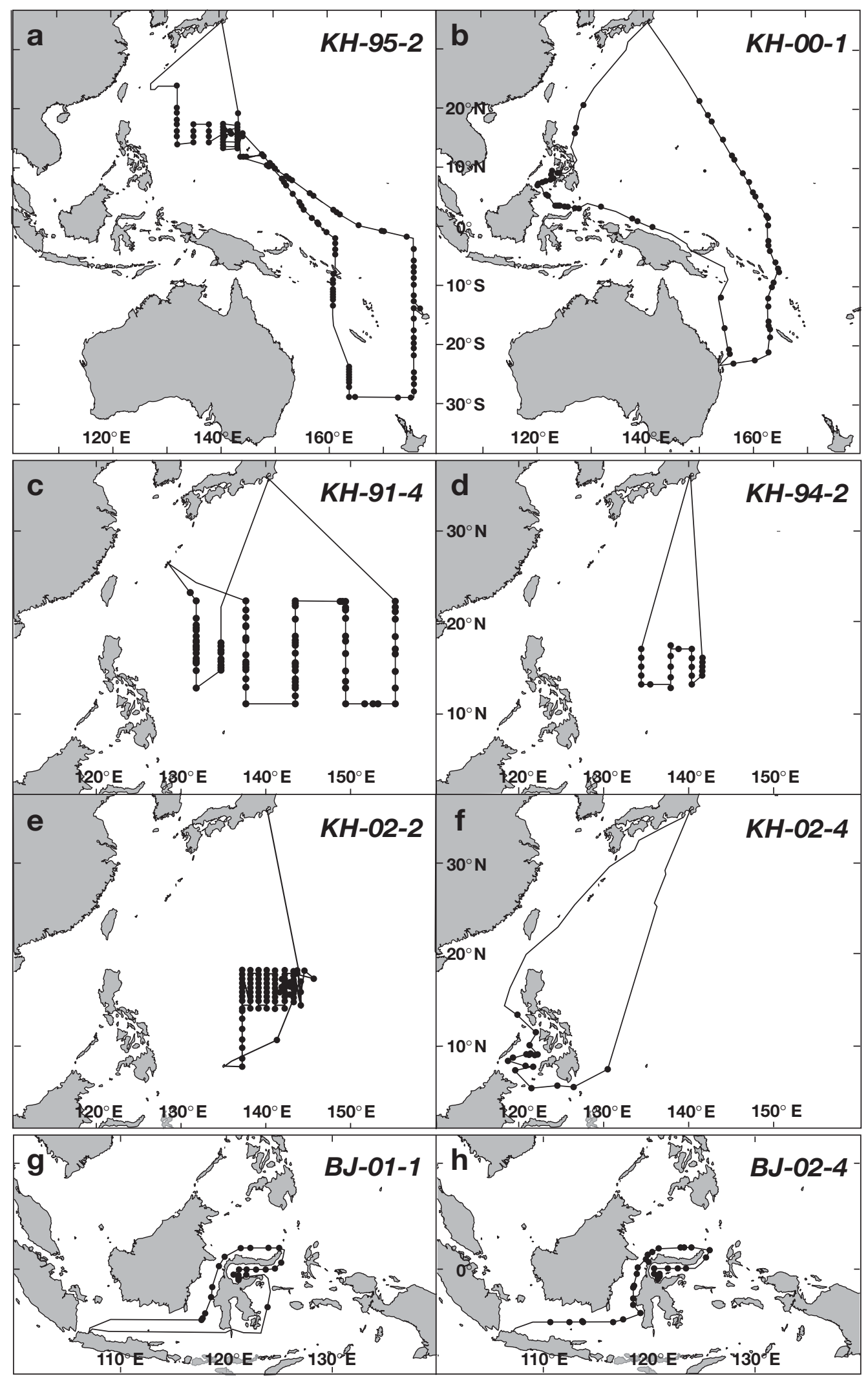

Fig. 1. Track charts and sampling stations during the 8 cruises of the RV 'Hakuho Maru' (KH) and the RV 'Baruna Jaya VII' (BJ) in the western Pacific and Indonesian Seas that were included in this study 
Growth analysis. Growth was analyzed in 3 different ways. (1) Linear regressions of the relationship between TL and age were performed on specimens up to $80 \mathrm{~d}$ old, to enable comparisons among 4 species in this study and to previous studies that used linear regression with leptocephali that had not reached their maximum size (Castonguay 1987, Ishikawa et al. 2001, Shinoda 2004). Specimens older than 80 d were eliminated from the regressions because the growth rates appeared to slow down in some species as leptocephali approached their maximum size after $80 \mathrm{~d}$, but appeared to be linear in all 4 species before $80 \mathrm{~d}$. The slope of the regression lines should be the best estimates of the growth rate before the leptocephali approach their maximum size, and anaylsis of covariance (ANCOVA) was used to test for differences among the slopes (growth rates) of the regression lines of the 4 species. Afterwards, Scheffe's multiple comparison tests were used for each pair of data. (2) To examine the relationship between TL and age of all the leptocephali that were examined, the Gompertz growth curve was fitted to the data of each species. The equation model is: $L_{t}=L_{\infty}$. $\exp \left\{-\exp \left[-K\left(t-t_{0}\right)\right]\right\}$, where $L_{t}$ is the TL at age $t, L_{\infty}$ is the asymptotic length, $K$ is the growth coefficient and $t_{0}$ is the hypothetical age when the TL would be zero. These parameters were derived by non-linear least squares using SOLVER on MS-Excel. (3) To compare data with previous studies in which a limited size range of specimens was obtained (Tsukamoto et al. 1989, 1992, Arai et al. 2001a), individual growth rates of leptocephali were calculated as: $(\mathrm{TL}-3) \mathrm{age}^{-1}$, because a mean length of $3 \mathrm{~mm}$ at hatching was obtained for artificially fertilized Anguilla japonica (Yamamoto \& Yamauchi 1974). Differences among these growth rates were tested by analysis of variance (ANOVA) and afterwards by Scheffe's multiple comparison tests for each pair of data.

The daily depositions of otolith increments have been validated in the post-recruitment glass eels of temperate anguillid species (Tsukamoto 1989, Martin 1995) and in the tropical species Anguilla marmorata (Sugeha et al. 2001a) and A. celebesensis (Arai et al. 2000). Although there has been doubt about whether or not daily deposition of otolith increments occurs in some phases during the late leptocephalus or oceanic glass eel stage of Atlantic eels (Cieri \& McCleave 2000), daily increment deposition during the lepto- cephalus and glass eel stages of anguillids, especially tropical eels, appears to be likely, because of the clear and regular increment deposition from the hatch check to the edge of the otolith of glass eels that recruited to an estuary. In addition, a recent validation study of increment periodicity demonstrated the daily deposition of increments during both preleptocephalus and leptocephalus stages using artificially reared larvae of A. japonica (Shinoda et al. 2004). Therefore, because the microstructure of otoliths and the pattern of change in incremental width were fundamentally the same between the 2 species that have undergone validation studies (A. marmorata and A. celebesensis) and the other 2 species that have not yet been validated ( $A$. bicolor pacifica and A. borneensis), we assumed that the latter 2 species also deposited daily increments in their otoliths.

\section{RESULTS}

\section{Distribution of eel larvae}

We collected 219 larvae of the tropical anguillid eels Anguilla marmorata, A. bicolor pacifica, A. celebesensis and $A$. borneensis, and most of these were premetamorphic leptocephali (Figs. 2 \& 3). A. marmorata and $A$. bicolor pacifica were widely collected in most sampling areas in the western Pacific (Fig. 2).

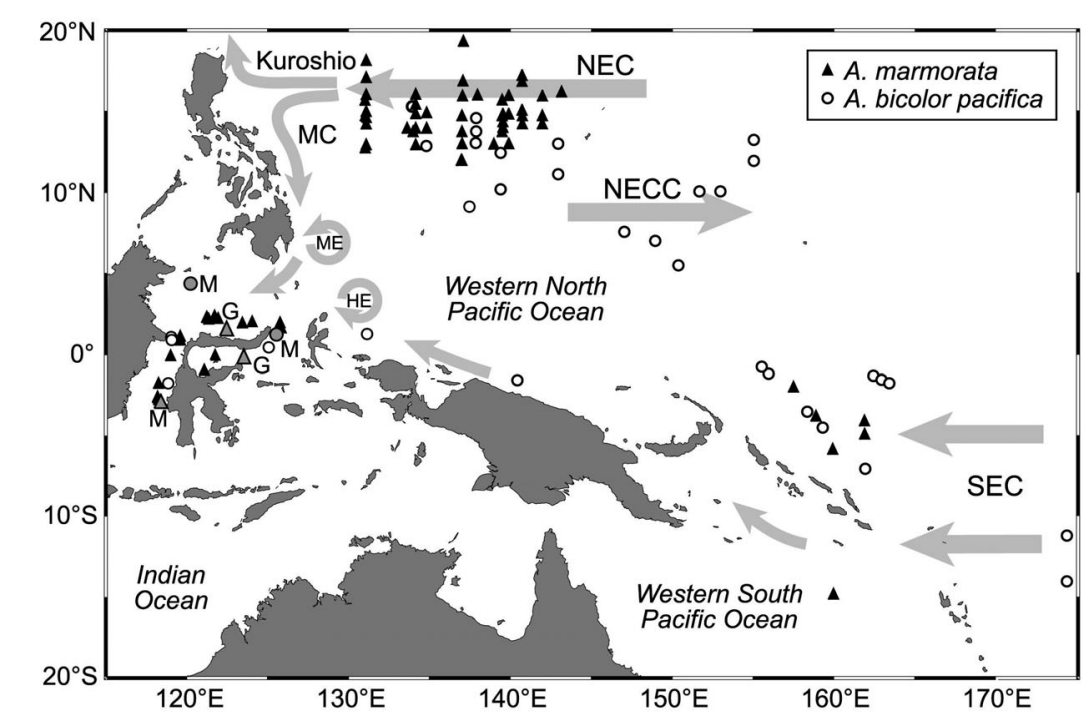

Fig. 2. Anguilla marmorata, A. bicolor pacifica. Collection of leptocephali in relation to the major current systems in the western Pacific region. The major current features of the region are the North Equatorial Current (NEC), North Equatorial Countercurrent (NECC), Mindanao Current (MC), Mindanao Eddy (ME), Halmahera Eddy (HE) and South Equatorial Current (SEC). M: metamorphosing leptocephali; G: glass eels 
Anguilla marmorata was collected in the greatest abundance ( $\mathrm{n}=124,9.6$ to $50.7 \mathrm{~mm}$ ), with 83 leptocephali being collected in the NEC region to the west of the Mariana Islands at a size range of 9.6 to $56.7 \mathrm{~mm}$ (Table 1, Fig. 4). Small recently hatched leptocephali of A. marmorata $(<20 \mathrm{~mm})$ were only collected in the eastern NEC area between June and July of 4 different years, while only larger specimens occurred around Sulawesi Island (28.0 to $50.7 \mathrm{~mm}$ ). A $46.3 \mathrm{~mm}$ metamorphosing leptocephalus and 47.8 and $48.6 \mathrm{~mm}$ oceanic glass eels of $A$. marmorata were also collected around Sulawesi Island (Fig. 2). A. marmorata collected in the western South Pacific (WSP) to the east of New Guinea were of intermediate size (21.3 to $47.3 \mathrm{~mm}$ ).

Anguilla bicolor pacifica also occurred widely ( $\mathrm{n}=$ $45,24.0$ to $54.1 \mathrm{~mm}$ ), with large-sized specimens being collected in the NEC and North Equatorial Counter Current (NECC) regions (40.0 to $50.5 \mathrm{~mm}$ ), mid-size leptocephali (24.0 to $48.0 \mathrm{~mm}$ ) to the east of New Guinea, and larger specimens, including metamorphosing leptocephali, being collected around Indonesia ( 42.6 to $49.5 \mathrm{~mm}$, Figs. 2 \& 4). The metamorphosing leptocephali collected around Sulawesi Island were 42.6 and $46.3 \mathrm{~mm}$. The $11 \mathrm{~A}$. bicolor pacifica in the WSP ranged in size from 29.3 to $54.1 \mathrm{~mm}$.

Anguilla celebesensis ( $\mathrm{n}=42,12.3$ to $47.8 \mathrm{~mm}$ ) were collected only within the Indonesian Archipelago in the Celebes Sea and Tomini Bay (Fig. 3). Small specimens of $A$. celebesensis were collected in the Celebes Sea $(12.3 \mathrm{~mm})$ and Tomini Bay (13.0 mm), but 36 leptocephali of 2 size classes were collected in Tomini Bay in May 2001 (Fig. 4). A similar survey in Tomini Bay was also conducted in October 2002, but no anguillid leptocephali were collected.

Similarly, small to fully grown leptocephali of Anguilla borneensis ( $\mathrm{n}=8,8.5$ to $49.0 \mathrm{~mm}$ ) were collected only around the Indonesian Archipelago in the Sulu Sea, Celebes Sea, Maluku Sea and Makassar Strait (Figs. 3 \& 4). The smallest leptocephalus of $A$. borneensis $(8.5 \mathrm{~mm})$ was collected in February, just after hatching in the Celebes Sea. A metamorphosing leptocephalus of $A$. borneensis (49.1 mm) was collected in the Sulu Sea near Borneo Island.

\section{Age and growth}

The microstructure of the otoliths of all 4 species was fundamentally the same and enabled the number of increments to be

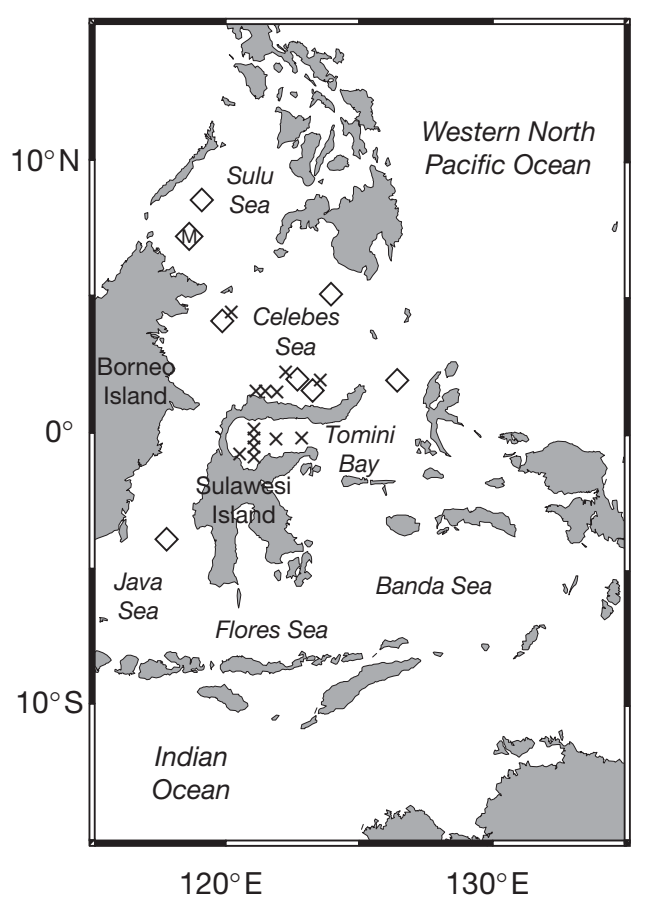

Fig. 3. Anguilla celebesensis, A. borneensis. Collection locations around Sulawesi Island, Indonesia. Leptocephali are shown by crosses for $A$. celebesensis and diamonds for A. borneensis. Letter in symbol indicates a metamorphosing leptocephalus (M) of $A$. borneensis

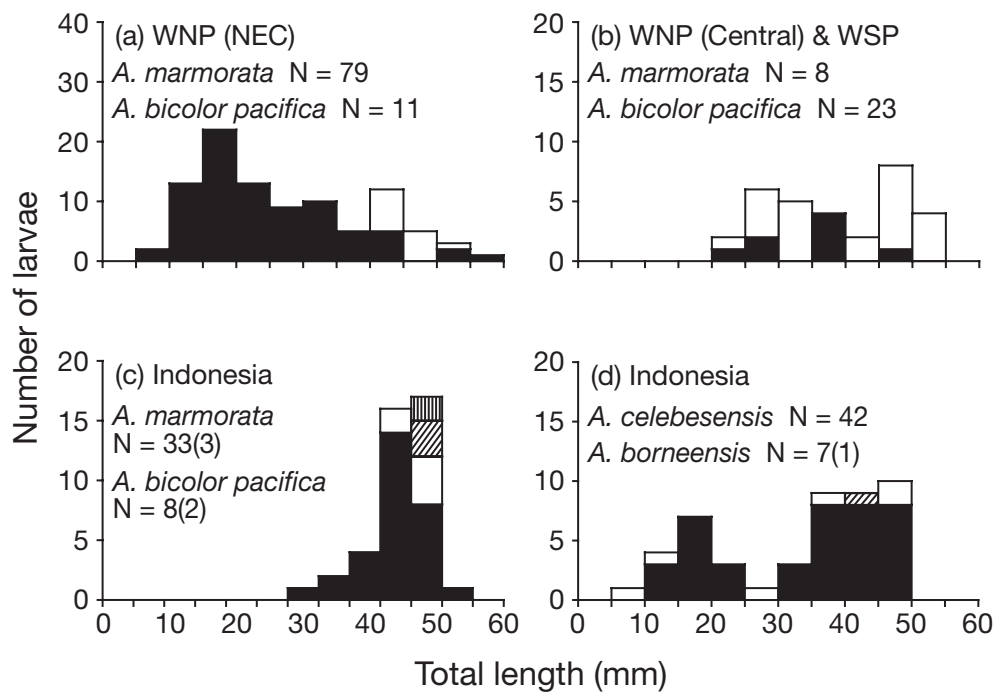

Fig. 4. Anguilla spp. Length-frequency distributions of the larvae of 4 tropical eel species. (a-c) Sizes of pre-metamorphic leptocephali of $A$. marmorata (black bars) and A. bicolor pacifica (white bars), and the metamorphosing leptocephali of $A$. marmorata and A. bicolor pacifica (angled pattern) and oceanic glass eels of $A$. marmorata (vertical pattern), with the number of specimens of these stages in parentheses. These larvae were collected in the North Equatorial Current region (NEC) north of $8^{\circ} \mathrm{N}$, the southern part of the western North Pacific (WNP) between $8^{\circ} \mathrm{N}$ and the equator, in the western South Pacific (WSP), or in Indonesia. (d) Leptocephali of $A$. celebesensis (black bars) and $A$. borneensis (white bars), and a metamorphosing leptocephalus of $A$. borneensis (angled pattern) 

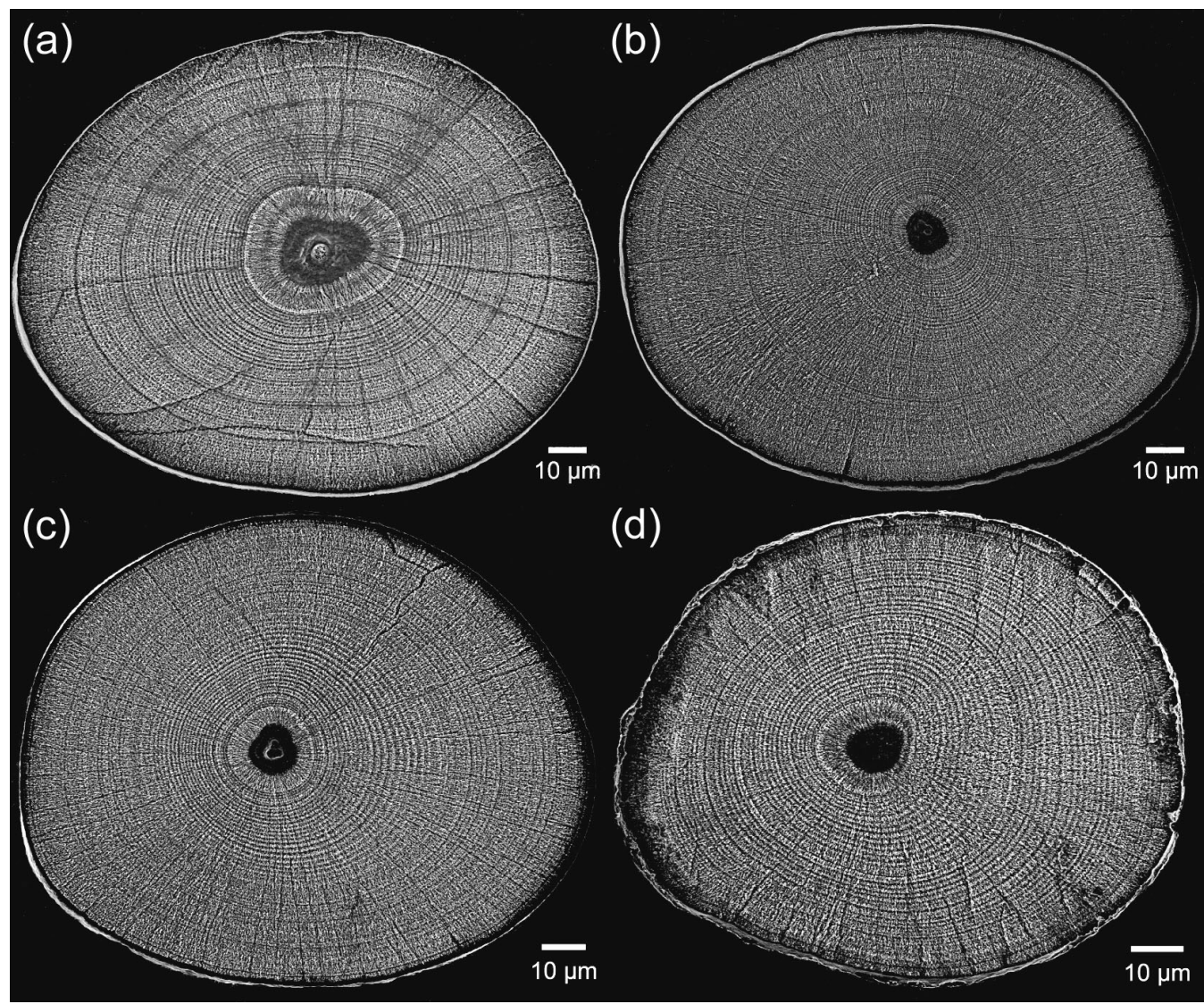

Fig. 5. Anguilla spp. SEM photographs of the otoliths of leptocephali of: (a) A. marmorata (28.0 mm), (b) A. bicolor pacifica $(47.0 \mathrm{~mm}),(\mathrm{c})$ A. celebesensis $(37.5 \mathrm{~mm})$ and (d) A. borneensis $(42.0 \mathrm{~mm})$

counted in each otolith (Fig. 5). Each etched otolith had a core that was observed as a deep hole, and the increments could be observed clearly out to the edge of the otolith in all species. The ages of larvae estimated based on the number of otolith daily increments varied greatly, because of the wide size range of larvae exam- ined. The ages of Anguilla marmorata were 22 to $137 \mathrm{~d}$ in leptocephali, $147 \mathrm{~d}$ in the metamorphosing leptocephalus and 159 and $160 \mathrm{~d}$ in oceanic glass eels (Table 2). The ages of $A$. bicolor pacifica ranged from 40 to $128 \mathrm{~d}$ in leptocephali, and were 106 and $112 \mathrm{~d}$ in metamorphosing leptocephali. The ages of A. celebe-

Table 2. Anguilla spp. Total length and age of each development stage of anguillid larvae, and the number of specimens and range in ages used for otolith analysis

\begin{tabular}{|c|c|c|c|c|c|}
\hline Species & $\begin{array}{l}\text { Development } \\
\text { stage }\end{array}$ & $\begin{array}{c}\text { Total no. } \\
\text { of specimens }\end{array}$ & $\begin{array}{l}\text { Total length } \\
\text { (mm) }\end{array}$ & $\begin{array}{l}\text { No. for otolith } \\
\text { analysis }\end{array}$ & $\begin{array}{l}\text { Age } \\
\text { (d) }\end{array}$ \\
\hline \multirow[t]{3}{*}{ A. marmorata } & Leptocephali & 121 & $8.0-50.7$ & 42 & $22-137$ \\
\hline & Metamorphosing leptocephali & 1 & 46.3 & 1 & 147 \\
\hline & Oceanic glass eels & 2 & $47.8,48.6$ & 2 & 159,160 \\
\hline \multirow[t]{2}{*}{ A. bicolor pacifica } & Leptocephali & 43 & $24.0-54.1$ & 29 & $40-128$ \\
\hline & Metamorphosing leptocephali & 2 & $42.6,46.3$ & 2 & 106,112 \\
\hline A. celebesensis & Leptocephali & 42 & $12.3-47.8$ & 40 & $17-110$ \\
\hline \multirow[t]{2}{*}{ A. borneensis } & Leptocephali & 7 & $8.5-49.0$ & 6 & $20-106$ \\
\hline & Metamorphosing leptocephali & 1 & 49.1 & 1 & 133 \\
\hline
\end{tabular}


sensis leptocephali ranged from 17 to $110 \mathrm{~d}$. A. borneensis were aged 20 to $106 \mathrm{~d}$ in leptocephali and $133 \mathrm{~d}$ in the metamorphosing leptocephalus.

The ages of leptocephali were linearly related to TL in each species up to ages of about 80 to $100 \mathrm{~d}$, when growth rates appeared to slow down (Fig. 6). The growth of Anguilla marmorata and A. bicolor pacifica appeared to reach a plateau, showing their full grown size at about $100 \mathrm{~d}$, while $A$. celebesensis and $A$. borneensis reached full size at about $80 \mathrm{~d}$ (Fig. 6). It is significant that all 4 species showed almost the same full grown size of around $50 \mathrm{~mm}$ (Fig. 6). For comparisons of growth rates during the early growth period before the leptocephali reached their maximum size, regressions of the TL and age up to $80 \mathrm{~d}$ were made. All species appeared to show approximately linear growth during this period. These regressions for A. marmorata $\left(y=0.42 x+6.26, \mathrm{r}^{2}=0.82\right)$, A. bicolor pacifica $(y=$ $\left.0.48 x+7.08, r^{2}=0.81\right), A$. celebesensis $(y=0.55 x+$ $\left.3.55, \mathrm{r}^{2}=0.96\right)$ and $A$. borneensis $\left(y=0.61 \mathrm{x}+0.21, \mathrm{r}^{2}=\right.$ 0.99 ) indicated that the overall growth rates of these species for the period up to $80 \mathrm{~d}$ old were $0.42,0.48$, 0.55 and $0.61 \mathrm{~mm} \mathrm{~d}^{-1}$, respectively. Statistical tests showed a significant difference in the slope of regres-

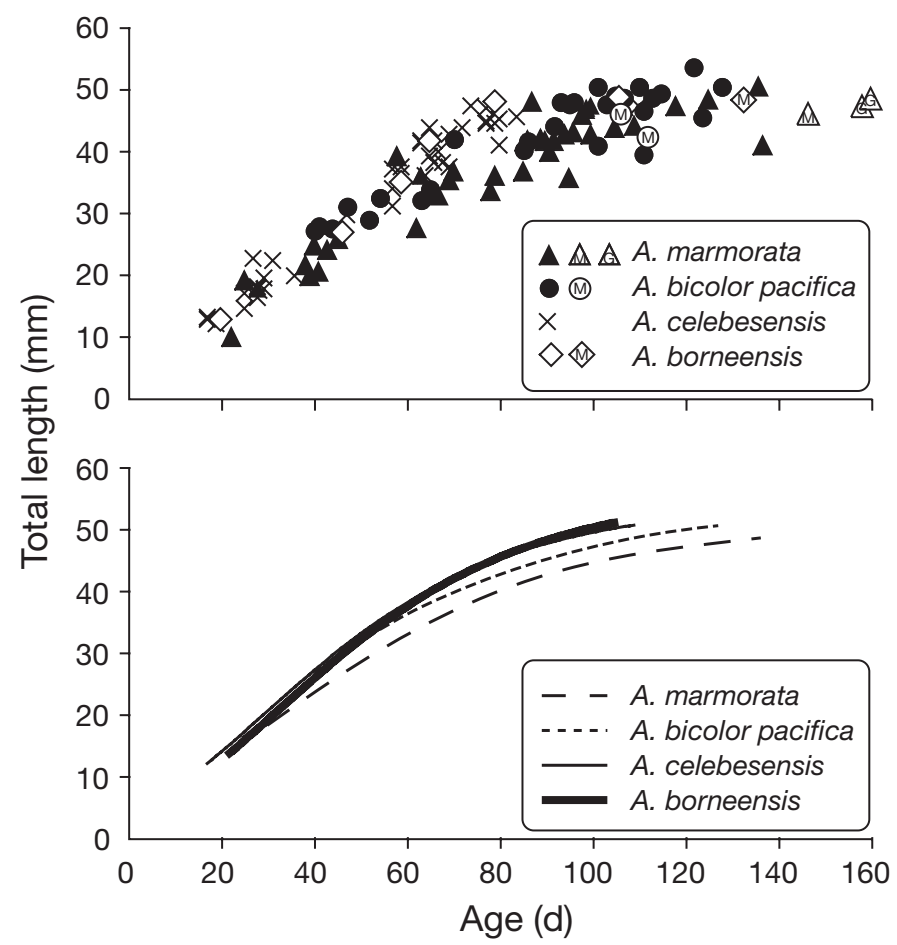

Fig. 6. Anguilla spp. Plots of the ages and total lengths of the leptocephali of $A$. marmorata (triangles), A. bicolor pacifica (circles), A. celebesensis (crosses) and A. borneensis (diamonds) with the metamorphosing leptocephali (M) and glass eels (G) of some species indicated by letters within the symbols (top panel). Gompertz growth curves fitted to the data of all specimens of each of the 4 species (bottom panel) sion lines among species (ANCOVA, $\mathrm{p}<0.01$ ). The 2 species that have local spawning areas in the Indonesian Seas, A. celebesensis and A. borneensis, had higher growth rates than the A. marmorata leptocephali, which were likely spawned in the WNP, A. bicolor pacifica also had a higher growth rate than A. marmorata (Scheffe's test, $\mathrm{p}<0.01$ ).

The Gompertz growth curves fitted to the TL and age data were as follows: Anguilla marmorata $\left(L_{t}=50.7 \cdot \exp \right.$ $\left.\{-\exp [-0.03(t-31.43)]\}, \mathrm{r}^{2}=0.90\right)$, A. bicolor pacifica $\left(L_{t}=\right.$ $\left.53.8 \cdot \exp \{-\exp [-0.03(t-27.6)]\}, \mathrm{r}^{2}=0.85\right)$, A. celebesensis $\left(L_{t}=54.1 \cdot \exp \{-\exp [-0.03(t-29.7)]\}, \mathrm{r}^{2}=0.97\right)$ and A. borneensis $\left(L_{t}=55.7 \cdot \exp \{-\exp [-0.03(t-33.1)]\}, \mathrm{r}^{2}=\right.$ $0.98)$. These curves indicated that $A$. celebesensis and A. borneensis showed similar growth rates that were slightly faster than those of the other 2 species and that A. bicolor pacifica may have had a slightly faster growth rate than A. marmorata (Fig. 6).

The mean individual growth rate of all the leptocephali of each species ranged from $0.44 \pm 0.07 \mathrm{~mm} \mathrm{~d}^{-1}$ (mean $\pm \mathrm{SD}$ ) in Anguilla marmorata to $0.47 \pm 0.08 \mathrm{~mm}$ $\mathrm{d}^{-1}$ in A. bicolor pacifica, $0.52 \pm 0.05 \mathrm{~mm} \mathrm{~d}^{-1}$ in $A$. borneensis and $0.56 \pm 0.06 \mathrm{~mm} \mathrm{~d}^{-1}$ in A. celebesensis (Fig. 7). However, because the growth of leptocephali appeared to slow down as they reached their maximum size, a statistical comparison among species was only done on the leptocephali that were $\leq 80 \mathrm{~d}$ old, to exclude those specimens whose growth rate may have slowed down. For these specimens, there was a significant difference in the mean individual growth rates among species (ANOVA, p < 0.01), with there being significant differences between $A$. bicolor pacifica and A. celebesensis and between A. marmorata and A. celebesensis (Scheffe's test, $\mathrm{p}<0.01$ ), but no significant difference between $A$. marmorata and $A$. bicolor pacifica. The sample size of $A$. borneensis was too small to include it in the comparisons.

\section{Hatching dates}

The estimated hatching dates that were back-calculated from the sampling date and age differed throughout the year for the 4 species examined. The hatching dates were from November to February and from late May to early August for Anguilla marmorata, from late December to early August for A. bicolor pacifica, in early August and from mid-January to early May for A. celebesensis and from February to September for A. borneensis (Fig. 8). Most of A. marmorata and $A$. bicolor pacifica that were collected in the NEC region had hatching dates during the April to August period, while those collected in the western Pacific or Indonesian Seas were born from November to March. Most of the A. celebesensis caught in Tomini Bay had 

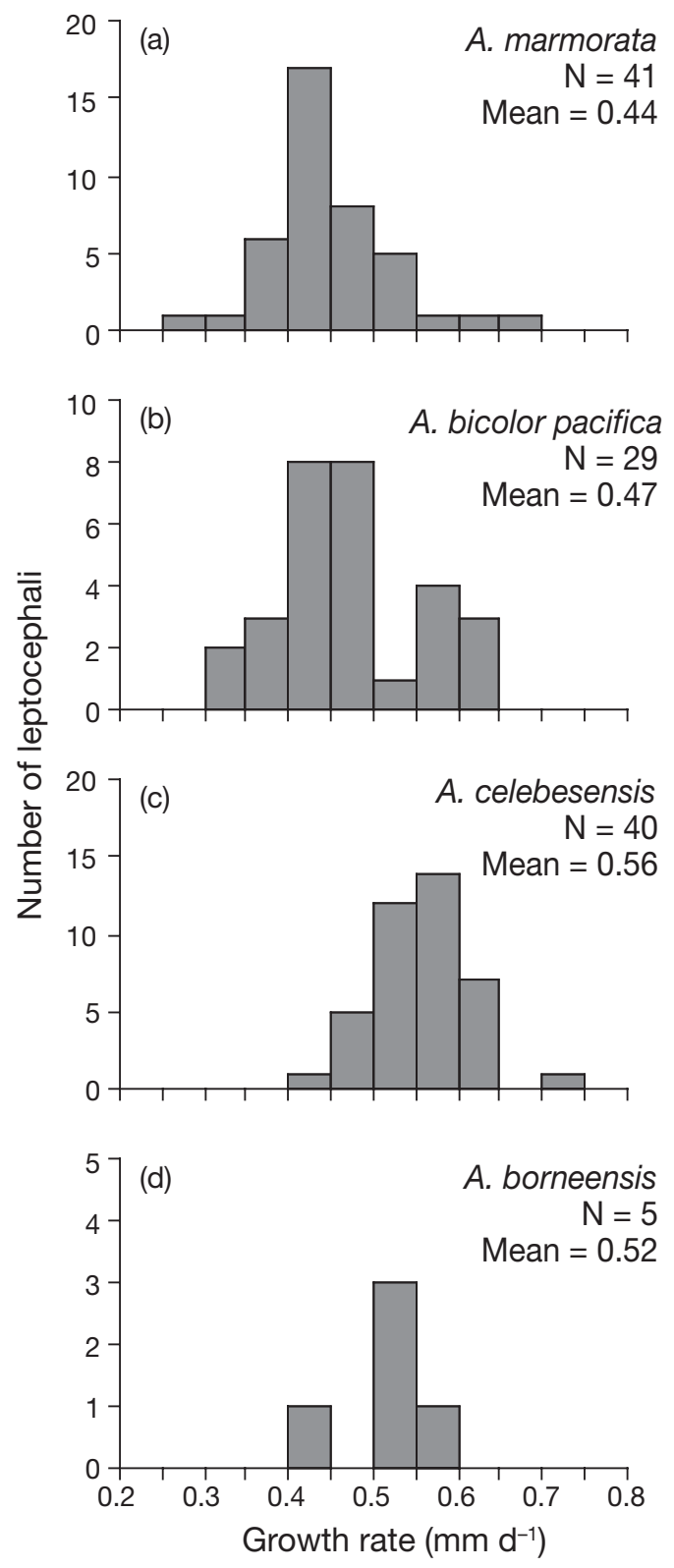

Fig. 7. Anguilla spp. Frequency distributions of the individual growth rates of pre-metamorphic leptocephali of: (a) A. marmorata, (b) A. bicolor pacifica, (c) A. celebesensis and (d) A. borneensis collected in the western Pacific and Indonesian Seas hatching dates from January to May. However, these results may have been derived from limited sampling efforts in each region.

\section{DISCUSSION}

\section{Distribution and migration of leptocephali}

The geographic distributions and size ranges of leptocephali in the various sampling areas were different among species. Anguilla celebesensis and A. borneensis were collected only around the Indonesian Archipelago. Small specimens of $A$. celebesensis were collected in the Celebes Sea and Tomini Bay, suggesting spawning by that species in 2 different areas. The smallest leptocephalus of $A$. borneensis, just after hatching, was collected in the Celebes Sea. A. borneensis was only collected in the Celebes, Sulu and Maluku Seas and at the southern end of the Makassar Strait, which is consistent with spawning close to their freshwater growth habitats on eastern Borneo Island (Ege 1939) and the general surface current patterns of the region (Miyama et al. 1995). Thus, we confirmed that both the tropical eels A. celebesensis and A. borneensis show small-scale local migrations of less than a few hundred kilometers to spawn over deep water relatively close to their juvenile growth habitats in freshwater and that their leptocephali have short migrations to return to their recruitment areas.

In contrast to these 2 species with small ranges of distribution, Anguilla marmorata and A. bicolor pacifica were widely collected in most sampling areas in the western Pacific (Fig. 2). Small A. marmorata leptocephali were collected only to the west of the Mariana Islands, while only larger specimens and more developed metamorphosing leptocephali or oceanic glass eels occurred in the more western areas, especially around Indonesia. A. marmorata collected near the equator east of New Guinea and in the South Pacific were of intermediate size. A. bicolor pacifica also occurred widely, with mid-size leptocephali collected only to the east of New Guinea and larger specimens

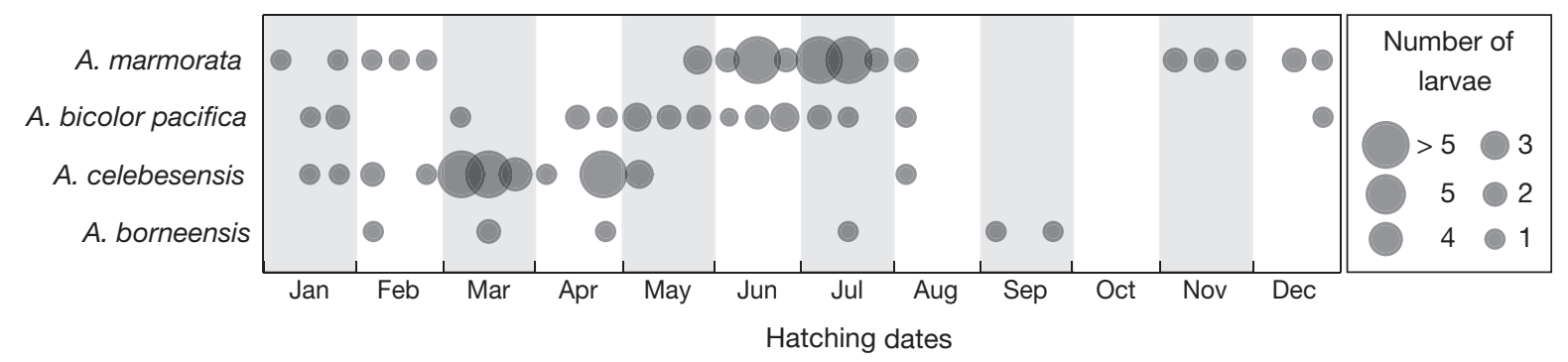

Fig. 8. Anguilla spp. Back-calculated hatching dates of 4 species of tropical eels based on the otolith microstructure of their leptocephali collected in the western Pacific and Indonesian Seas during this study 
including metamorphosing larvae being collected around Indonesia and west of the Mariana Islands.

The distribution of Anguilla marmorata leptocephali collected during 5 different years in the NEC indicates that a spawning area of this species is located to the west of the Mariana Islands in an overlapping area with the spawning area of the Japanese eel. Spawning in this area by $A$. marmorata would result in its leptocephali being first transported westward by the NEC, which bifurcates at about $127^{\circ} \mathrm{E}$ to the east of the Philippine Islands (Toole et al. 1990), into either the northward flow of the Kuroshio Current or the southward flow of the Mindanao Current (Lukas et al. 1991, Fine et al. 1994). The leptocephali that enter the Kuroshio recruit to the northern Philippines or southern areas of East Asia, and those that enter the Mindanao Current recruit to the southern Philippines or northern Indonesia. A recent study of population genetics has shown that $A$. marmorata has as many as 6 different populations throughout its range in the western Pacific and Indian Oceans (Ishikawa et al. 2004). According to this finding, the leptocephali collected in the western North Pacific and northern Indonesian Seas belong to the same population (North Pacific population), which appears to spawn in the NEC, while those collected east of New Guinea and in the South Pacific are from different populations (western South Pacific population or Tahiti population, in Ishikawa et al. 2004).

We speculate that Anguilla bicolor pacifica in the WNP region spawns in the western Pacific, somewhere near New Guinea, and recruits mostly to Indonesia, or they may have $>1$ spawning area in the WNP, but the lack of collection of any small leptocephali of this species has so far made determination of their spawning area difficult. However, the hypothesis that A. bicolor pacifica spawns outside of the Indonesian Seas and that their leptocephali are transported there by ocean currents is supported by evidence indicating that the ages of glass eels of both $A$. marmorata and $A$. bicolor pacifica recruiting to Indonesia (155 \pm 14.8 and $173 \pm$ 20.9 d, respectively, Arai et al. 2001b; $170 \pm 15.9$ and $195 \pm 25.8$ d, respectively, Marui et al. 2001) are consistently older than those of $A$. celebesensis $(109 \pm 10.9 \mathrm{~d}$, Arai et al. 2001b; $116 \pm 17.7$ d, Marui et al. 2001). The presence of leptocephali widely scattered in the NEC, NECC and SEC in the western Pacific clearly suggests that $A$. bicolor pacifica, like A. marmorata, may have multiple spawning areas.

\section{Growth and size at metamorphosis}

The ages of anguillid larvae of these 4 species estimated by otolith daily increments varied greatly (17 to $160 \mathrm{~d}$ for specimens of 10.1 to $54.1 \mathrm{~mm}$ ), and their daily growth rates were somewhat different among species. The ages of all 4 species were linearly related to TL during the first $80 \mathrm{~d}$, with Anguilla celebesensis and $A$. borneensis having higher growth rates than $A$. marmorata and $A$. bicolor pacifica. The growth rates of A. celebesensis and A. borneensis were also shown to be faster by fitting the Gompertz growth curves with the data of all specimens. The best growth estimates were likely those for the leptocephali up to $80 \mathrm{~d}$, before growth rates may have slowed down. The Gompertz growth curves and the lack of apparent increase in TL in the older leptocephali examined in this study suggested that the growth rates slowed down as the leptocephali reached their maximum sizes.

Although the growth rates were different in some of the species, the relationship between TL and age suggested that all species might reach a similar maximum size as leptocephali. The growth of Anguilla marmorata and A. bicolor pacifica leptocephali appeared to reach a plateau, showing their fully grown size at about $100 \mathrm{~d}$, while $A$. borneensis and $A$. celebesensis appeared to reach full size at about $80 \mathrm{~d}$. These samples of leptocephali, metamorphosing leptocephali and glass eels indicated that the maximum size of these 4 tropical species of leptocephali is probably around $50 \mathrm{~mm}$ TL. This is similar to the maximum size of tropical leptocephali reported from this region by Jespersen (1942).

The maximum sizes and growth rates of the leptocephali of these 4 species of tropical leptocephali are considerably different than the estimates of these characteristics for several temperate species. The maximum sizes of the leptocephali of temperate anguillids, such as the 2 Atlantic eel species (Jespersen 1942, Kleckner et al. 1985) and the Japanese eel (Tsukamoto \& Umezawa 1990), appear to be about 60 to $75 \mathrm{~mm}$, which are much larger than those for the tropical species examined in this study (Table 3). Studies on the otolith microstructure of these temperate species have indicated that the growth rates of the leptocephali of Atlantic eels (0.38 $\mathrm{mm} \mathrm{d}^{-1}$, Castonguay 1987) may be considerably smaller than those of the species examined here (Table 3). The leptocephali of the Japanese eel also appear to grow somewhat more slowly than most of the tropical eel leptocephali of this study, acccording to otolith microstructure studies by Ishikawa et al. (2001) and Shinoda (2004), which found growth rates of 0.46 and $0.43 \mathrm{~mm} \mathrm{~d}^{-1}$, respectively, based on regression data. The growth rates of the leptocephali of Atlantic eels have been estimated to be even slower (0.18 to $0.24 \mathrm{~mm} \mathrm{~d}^{-1}$ ) using length frequency data (Boëtius \& Harding 1985, Kleckner et al. 1985), but these studies did not examine growth rates using otoliths. Therefore, growth rates estimated from the slope of linear regressions calculated from the collection dates and TLs may be underestimates. 
Table 3. Anguilla spp. Approximate distances of migration from shortest to longest, and maximum sizes and growth rates of temperate and tropical species of anguillid leptocephali that have been studied. Growth rates are based on the regressions of total length (TL) and age $\left(\mathrm{GR}^{* 1}\right)$ and the mean individual growth $\left(\mathrm{GR}^{* 2}\right)$ of leptocephali for each species

\begin{tabular}{|c|c|c|c|c|c|c|}
\hline \multirow{2}{*}{ Species } & \multirow{2}{*}{$\begin{array}{l}\text { Migration } \\
\text { distance } \\
(\mathrm{km})\end{array}$} & \multicolumn{2}{|c|}{ Full grown size } & \multirow[b]{2}{*}{$\begin{array}{c}\mathrm{GR}^{* 1} \\
\left(\mathrm{~mm} \mathrm{~d}^{-1}\right)\end{array}$} & \multicolumn{2}{|c|}{ - Growth rate - } \\
\hline & & $\mathrm{TL}(\mathrm{mm})$ & Source & & $\begin{array}{c}\mathrm{GR}^{* 2} \\
\left(\mathrm{~mm} \mathrm{~d}^{-1}\right)\end{array}$ & Source \\
\hline \multicolumn{7}{|l|}{ Temperate } \\
\hline A. anguilla & 5000 & 75 & Jespersen (1942) & 0.38 & & Castonguay (1987) \\
\hline A. rostrata & 2500 & 70 & Kleckner et al. (1985) & 0.38 & & Castonguay (1987) \\
\hline A. japonica & 2500 & 60 & $\begin{array}{l}\text { Tsukamoto \& } \\
\text { Umezawa (1990) }\end{array}$ & 0.43 & & Shinoda (2004) \\
\hline \multicolumn{7}{|l|}{ Tropical } \\
\hline A. marmorata & 1000 & 50 & Present study & 0.42 & 0.44 & Present study \\
\hline A. bicolor pacifica & 1000 & 50 & Present study & 0.48 & 0.47 & Present study \\
\hline A. celebesensis & 50 & 50 & Present study & 0.55 & 0.56 & Present study \\
\hline A. borneensis & 100 & 50 & Present study & 0.61 & 0.52 & Present study \\
\hline
\end{tabular}

These different growth rates of anguillid leptocephali are likely influenced by various environmental factors in the different regions where these species are found. One factor is the variation in water temperature at different latitudes and in different seasons in the tropical and subtropical regions where anguillid leptocephali have been collected. Anguillid leptocephali are found in the upper few hundred meters of the ocean (Castonguay \& McCleave 1987, Otake et al. 1998), and so they primarily experience surface temperatures that range from about 25 to $30^{\circ} \mathrm{C}$ in the western Pacific or slightly colder temperatures in the southern Sargasso Sea that range from about 23 to $28^{\circ} \mathrm{C}$ (Large \& Nurser 2000). The Indonesian Seas are located on both sides of the equator, and likely have the least variation in surface-water temperature, which mostly ranged from about $28^{\circ} \mathrm{C}$ (October) to $30^{\circ} \mathrm{C}$ (May) in this and a previous study (Ilahude \& Gordon 1996). The semi-enclosed Tomini Bay of Sulawesi Island, where the majority of the Anguilla celebesensis leptocephali were collected during this study, had surface-water temperatures as high as $30^{\circ} \mathrm{C}$. Another factor that may influence the growth of fish is the availability of food, but the food sources of anguillid leptocephali have been suggested to be detrital particles in the ocean, such as discarded larvacean houses and zooplankton fecal pellets (Mochioka \& Iwamizu 1996), or marine snow (Otake 1996), which are abundant in the pycnocline of the surface layer of the ocean. Therefore, the availability of food may not have a major influence on the growth of leptocephali. In addition, species-specific genetic traits, such as differences in the endogenous physiological properties of metabolic rate and assimilation rate, or locomotive activities may also influence larval growth, but there is no information available on these factors at present.

\section{Seasonality of spawning of tropical eels}

The back-calculated hatching dates of the leptocephali examined in this study showed that these species of tropical eels appear to spawn at a variety of times throughout the year. Anguilla marmorata and A. bicolor pacifica showed the widest ranges of dates, but the hatching dates of all 4 species were spread out over at least an 8 mo period of the year. Similarly wide ranges of hatching dates have been obtained from otolith analyses of glass eels of A. marmorata, A. bicolor pacifica and A. celebesensis in the region (e.g. Arai et al. 2001b, Marui et al. 2001). Glass eels also recruit to Sulawesi Island throughout the year (Sugeha et al. 2001b), further supporting a prolonged spawning period in tropical eels. The downstream migration season of tropical anguillids in their freshwater habitats is very poorly known, but the data from these otolith studies suggest that at least some tropical species have seasonal spawning patterns very different from the distinct boreal autumn downstream migration season of temperate anguillid species in the northern hemisphere (Tesch 1977).

\section{Evolution of eel migration}

Knowledge about the worldwide distributions, types of spawning migrations and the phylogenetic relationships of anguillid eels suggests that the long spawning migration of temperate eels evolved from much shorter local migrations of tropical anguillids. Of the 18 species/subspecies of anguillid eels worldwide, two-thirds inhabit the tropics (Ege 1939, Castle \& Williamson 1974), with 7 species/subspecies living in and around Indonesia. A molecular study using mitochondrial DNA on the phylogeny of the genus Anguilla sug- 
gested that $A$. borneensis, which is endemic to Borneo Island, Indonesia, was one of the possible ancestral anguillid species (Aoyama et al. 2001). A. celebesensis and $A$. borneensis, which have small-scale migrations, were indicated to be more ancestral than A. marmorata and $A$. bicolor pacifica that have mid-scale migrations. This indicates that it is likely that the large-scale migration of temperate eels evolved from a mid-scale migration of tropical species, which was derived from the small-scale local migration of tropical species somewhere near the Indonesian Archipelago.

The spawning areas of Anguilla celebesensis and A. borneensis are relatively close to coastal waters in areas of the Celebes Sea and Tomini Bay in the Indonesian Archipelago that have a steep continental slope, to depths of 2000 to $3000 \mathrm{~m}$. The Indonesian Archipelago is surrounded by deep seas such as the Celebes and Sulu Seas, and a recent molecular phylogenetic study analyzing the full genome of mitochondrial DNA suggests that anguillid eels are closely related to the deep-sea swallower and gulper eels of the Saccopharyngiformes (Inoue et al. 2004). This suggests that freshwater eels originated from deep-sea fishes in the marine environment, which is also supported by the fact that all other families of the order Anguilliformes are marine fishes, such as the congers, morays, snake eels and pike eels.

These ancestral anguillids probably had rapid larval growth rates and early metamorphosis, and migrated short distances between their tropical spawning areas over deep waters near their juvenile habitats in freshwater. Their high growth rates may have played an important role in reducing the chance of leptocephali being transported far away from their freshwater habitats near the spawning area. However, variation in the growth rates of their leptocephali may have enabled some individuals to drift farther away and colonize new areas. Individuals transported to more northern regions during the leptocephalus stage must have eventually established separate migration loops between these northern freshwater growth habitats and their tropical spawning areas, as proposed by Tsukamoto et al. (2002), and this eventually led to the establishment of temperate species with long migrations and slower larval growth rates.

In the present day, there appear to be 3 types of anguillid species, based on the distance of their spawning and larval migrations and their larval growth and size at metamorphosis. First, there is the small-scale migration group that includes the tropical species Anguilla celebesensis and A. borneensis, with fast larval growth and small size at metamorphosis (Table 2). Second, there are the tropical species $A$. marmorata and $A$. bicolor pacifica, which exhibit much larger scale migrations in the WNP and Indonesian
Seas of up to a few thousand kilometers, and, compared to the migration of $A$. anguilla of several thousand kilometers, have an intermediate-scale migration. Third, there is the large-scale migration group of the temperate species in the Northern Hemisphere and $A$. australis in the WSP. The growth rates of leptocephali of the large-scale migratory species ( $A$. anguilla, A. rostrata, A. japonica) appear to be lower than those of the small-scale migratory species ( $A$. borneensis, A. celebesensis), and mid-scale migratory species such as $A$. marmorata may have intermediate growth values (Table 3). Both the intermediate- and large-scale migratory species have their spawning areas in the tropical open ocean, but their growth habitats are located in tropical and temperate freshwaters, respectively. Another difference between these 2 groups is that the maximum sizes of the leptocephali of the large-scale migration species are larger (about 60 to $75 \mathrm{~mm}$, Jespersen 1942, Kleckner et al. 1985, Tsukamoto \& Umezawa 1990) than those of the intermediate types (about $50 \mathrm{~mm}$, present study).

The growth rates of leptocephali and the size at which metamorphosis occurs are important factors influencing the distance of migration of anguillid eels, because they may have a major effect on recruitment location and recruitment success. The duration of the leptocephalus stage is much longer than that of metamorphosis, which appears to be about the same (16 to 19 d) among tropical species in the Indonesian Seas (Arai et al. 2001b). During metamorphosis the body surface area of leptocephali that is exposed to friction in the water column is reduced by $29 \%$ and the body water content also decreases from 93 to $<80 \%$ (Tsukamoto \& Umezawa 1994). This suggests that it may be more difficult for glass eels to stay in the water column in ocean currents than for leptocephali. Therefore, the metamorphosis from the leptocephalus to the glass eel will likely terminate the transportation of eels by currents. Since the timing of metamorphosis may be determined by the larval growth rate and maximum size, these 2 biological traits may be key factors influencing the variation in migratory patterns of anguillid eels.

The speed of the currents used by the leptocephali of each species is also an important factor, which has been studied by satellite-tracking Argos buoys in the case of Anguilla japonica (Kimura et al. 1994). The large-scale migratory species of leptocephali are transported long distances of up to thousands of kilometers by strong western boundary currents, such as the Kuroshio for A. japonica (Kimura et al. 1994, 1999) and the Gulf Stream for A. anguilla and A. rostrata (McCleave \& Kleckner 1987), while the mid-scale types may drift mostly in slower currents, such as the North and South Equatorial Currents, their counter- 
currents, or local currents that transport larvae only hundreds or a few thousand kilometers. These findings suggest that each anguillid species, at various migration scales, has a species-specific geographic migratory route influenced by differences in growth rates, maximum sizes and passive transportation speeds by currents.

The new information on the distribution, size and growth rates of tropical anguillid leptocephali in this study leads us to the hypothesis that in anguillid eels the growth rate and size at metamorphosis of leptocephali are important factors regulating their migratory range. The duration of the leptocephalus stage is important for influencing the oceanic migration of tropical eels from hatching to the recruitment to estuaries. The finding that 2 different migration types are used by tropical eels in the WNP and Indonesian Seas suggests that there may be similar variations in the larval growth rates and migration distances of other tropical eel species in the Indian Ocean and WSP that may be identified through future research.

Acknowledgements. We thank the captain, crew and technicians of the RV 'Hakuho Maru' and RV 'Baruna Jaya VII' for their help during these 8 cruises. We also thank all the other scientific members of these cruises for their assistance in the collection and sorting of the plankton, and we thank N. Mochioka, T. Otake and G. Minagawa for assistance in the measurement and identification of leptocephali, K. Shirakihara for help with the growth model, and H. Y. Sugeha for general support. This work was supported in part by Grantsin-Aid Numbers 07306022，07556046，08041139，08456094, 10460081 and 11691177 from the Ministry of Education, Science, Sports and Culture, Japan, and by Grant Number JSPSRFTF 97L00901 from the 'Research for the Future Program' of the Japan Society for the Promotion of Science. K.T. was supported by the Research Foundation 'Touwa Shokuhin Shinkoukai' and the Eel Research Foundation 'Noborikai'.

\section{LITERATURE CITED}

Aoyama J, Mochioka N, Otake T, Ishikawa S, Kawakami Y, Castle P, Nishida M, Tsukamoto K (1999) Distribution and dispersal of anguillid leptocephali in the western Pacific Ocean revealed by molecular analysis. Mar Ecol Prog Ser 188:193-200

Aoyama J, Nishida M, Tsukamoto K (2001) Molecular phylogeny and evolution of the freshwater eel, genus Anguilla. Mol Phylogenet Evol 20:450-459

Aoyama J, Wouthuyzen S, Miller MJ, Inagaki T, Tsukamoto K (2003) Short-distance spawning migration of tropical freshwater eels. Biol Bull (Woods Hole) 204:104-108

Arai T, Otake T, Tsukamoto K (1997) Drastic changes in otolith microstructure and microchemistry accompanying the onset of metamorphosis in the Japanese eel Anguilla japonica. Mar Ecol Prog Ser 161:17-22

Arai T, Limbong D, Tsukamoto K (2000) Validation of otolith daily increments in the tropical eel Anguilla celebesensis. Can J Zool 78:1078-1084

Arai T, Aoyama J, Ishikawa S, Otake T, Miller MJ, Inagaki T, Tsukamoto K (2001a) Early life history of tropical Anguilla leptocephali in the western Pacific Ocean. Mar Biol 138: 887-895

Arai T, Limbong D, Otake T, Tsukamoto K (2001b) Recruitment mechanisms of tropical eels, Anguilla spp.: implications for the evolution of oceanic migration in the genus Anguilla. Mar Ecol Prog Ser 216:253-264

Boëtius J, Harding EF (1985) A re-examination of Johannes Schmidt's Atlantic eel investigations. Dana 4:129-162

Castle PHJ, Williamson GR (1974) On the validity of the freshwater eel species Anguilla ancestralis Ege from Celebes. Copeia 2:569-570

Castonguay M (1987) Growth of American and European eel leptocephali as revealed by otolith microstructure. Can J Zool 65:875-878

Castonguay M, McCleave JD (1987) Vertical distribution, diel and ontogenetic vertical migration and net avoidance of leptocephali of Anguilla and other common species in the Sargasso Sea. J Plankton Res 9:195-214

Cieri MD, McCleave JD (2000) Discrepancies between otoliths of larvae and juveniles of the American eel: is something fishy happening at metamorphosis? J Fish Biol 57: $1189-1198$

Ege V (1939) A revision of the genus Anguilla Shaw: a systematic, phylogenetic and geographical study. Dana-Rep Carlsberg Found 16:1-256

Fine RA, Lukas R, Bingham FM, Warner MJ, Gammon RH (1994) The western equatorial Pacific: a water mass crossroads. J Geophys Res 99:63-80

Ilahude AG, Gordon AL (1996) Thermocline stratification within the Indonesian Seas. J Geophys Res 101: 12401-12409

Inoue GJ, Miya M, Tsukamoto K, Nishida M (2004) Mitogenomic evidence for elopomorph fishes (Teleostei) and the evolutionary origin of the leptocephalus larva. Mol Phylogenet Evol 32:274-286

Ishikawa $\mathrm{S}$, Suzuki K, Inagaki T, Watanabe $\mathrm{S}$ and 11 others (2001) Spawning time and place of the Japanese eel, Anguilla japonica, in the North Equatorial Current of the western North Pacific Ocean. Fish Sci 67:1097-1103

Ishikawa S, Tsukamoto K, Nishida M (2004) Genetic evidence for multiple geographic populations of the giant mottled eel Anguilla marmorata in the Pacific and Indian oceans. Ichthyol Res 51:343-353

Jellyman DJ (1987) Review of the marine life history of Australian temperate species of Anguilla. Am Fish Soc Symp $1: 276-285$

Jespersen P (1942) Indo-Pacific leptocephalids of the genus Anguilla: systematic and biological studies. Dana-Rep Carlsberg Found 22:1-128

Kimura S, Tsukamoto K, Sugumoto T (1994) Model for the larval migration of the Japanese eel: roles of the trade winds and salinity front. Mar Biol 119:185-190

Kimura S, Döös K, Coward AC (1999) Numerical simulation to resolve the issue of downstream migration of the Japanese eel. Mar Ecol Prog Ser 186:303-306

Kleckner RC, Wippelhauser GS, McCleave JD (1985) List of Atlantic Anguilla leptocephali-American material. Dana 4:99-128

Large WG, Nurser AJG (2000) Ocean surface water mass transformation. In: Siedler G, Church J, Gould J (eds) Ocean circulation \& climate: observing and modeling the global ocean. Academic Press, New York, p 317-337

Lukas R, Firing ER, Hacker P, Richardson PL, Collins CA, Fine R, Gammon R (1991) Observations of the Mindanao Current during the western Equatorial Pacific Ocean circulation study. J Geophys Res 96:7089-7104

Martin MH (1995) Validation of daily growth increments in 
otoliths of Anguilla rostrata (Lesueur) elvers. Can J Zool 73:208-211

Marui M, Arai T, Miller MJ, Jellyman DJ, Tsukamoto K (2001) Comparison of early life history between New Zealand temperate eels and Pacific tropical eels revealed by otolith microstructure and microchemistry. Mar Ecol Prog Ser 213:273-284

McCleave JD (1993) Physical and behavioural controls on the oceanic distribution and migration of leptocephali. J Fish Biol 43:243-273

McCleave JD, Kleckner RC (1987) Distribution of leptocephali of catadromous Anguilla species in the western Sargasso Sea in relation to water circulation and migration. Bull Mar Sci 41:789-806

Miller MJ, Mochioka N, Otake T, Tsukamoto K (2002) Evidence of a spawning area of Anguilla marmorata in the western North Pacific. Mar Biol 140:809-814

Miyama T, Awaji T, Akitomo K, Imasato N (1995) Study of seasonal transport variations in the Indonesian seas. J Geophys Res 100:20517-20541

Mochioka N, Iwamizu M (1996) Diet of anguillid larvae: leptocephali feed selectively on larvacean houses and fecal pellets. Mar Biol 125:447-452

Otake T (1996) Fine structure and function of the alimentary canal in leptocephali of the Japanese eel Anguilla japonica. Fish Sci 62:28-34

Otake T, Inagaki T, Hasumoto $\mathrm{H}$, Mochioka N, Tsukamoto K (1998) Diel vertical distribution of Anguilla japonica leptocephali. Ichthyol Res 45:208-211

Schmidt J (1925) The breeding places of the eel. Annu Rep Smithson Inst 1924:279-316

Shinoda A (2004) The ecology of inshore migration of the Japanese eel, Anguilla japonica. PhD thesis, University of Tokyo

Shinoda A, Tanaka H, Kagawa H, Obata H, Tsukamoto K (2004) Otolith microstructural analysis of reared larvae of Japanese eel Anguilla japonica. Fish Sci 70:339-341

Sugeha HY, Shinoda S, Marui M, Arai T, Tsukamoto K (2001a)

Editorial responsibility: Howard I. Browman (Associate Editor-in-Chief), Storebø, Norway
Validation of otolith daily increments in the tropical eels Anguilla marmorata. Mar Ecol Prog Ser 220:291-294

Sugeha, HY, Arai T, Miller MJ, Limbong D, Tsukamoto K (2001b) Inshore migration of the tropical eels Anguilla spp. recruiting to the Poigar River estuary on Sulawesi Island. Mar Ecol Prog Ser 221:233-243

Tesch FW (1977) The eel: biology and management of anguillid eels. Chapman and Hall, London

Toole JM, Millard RC, Wang Z, Pu S (1990) Observations of the Pacific North Equatorial Current bifurcation at the Philippine coast. J Phys Oceanogr 20:307-318

Tsukamoto K (1989) Otolith daily increments in the Japanese eel. Bull Jpn Soc Sci Fish 55:1017-1021

Tsukamoto K (1992) Discovery of the spawning area for the Japanese eel. Nature 356:789-791

Tsukamoto K, Umezawa A (1990) Early life history and oceanic migration of the eel, Anguilla japonica. Bull Soc Fr Jpn Oceanogr 28:188-198

Tsukamoto K, Umezawa A (1994) Metamorphosis: a key factor of larval migration determining geographic distribution and speciation of eels. In: Proc 4th Indo-Pac Conf Fac Fisheries, Kasetart University, Bangkok, p 231-248

Tsukamoto K, Umezawa A, Tabeta O, Mochioka N, Kajihara $\mathrm{T}$ (1989) Age and birth date of Anguilla japonica leptocephali collected in western North Pacific in September 1986. Nippon Suisan Gakk 55:1023-1028

Tsukamoto K, Aoyama J, Miller MJ (2002) Migration, speciation, and the evolution of diadromy in anguillid eels. Can J Fish Aquat Sci 59:1989-1998

Tsukamoto K, Lee TW, Fricke H (2003) Spawning area of the Japanese eel. In: Aida K, Tsukamoto K, Yamauchi K (eds) Eel biology. Springer-Verlag, Tokyo, p 121-140

Tsukamoto Y, Umezawa A, Tsukamoto K, Okiyama M (1992) A full grown leptocephali of Japanese eel collected from the western North Pacific. Nippon Suisan Gakk 58:2209

Yamamoto K, Yamauchi K (1974) Sexual maturation of Japanese eel and production of eel larvae in the aquarium. Nature 251:220-222

Submitted: April 8, 2005; Accepted: September 9, 2005 Proofs received from author(s): January 19, 2006 